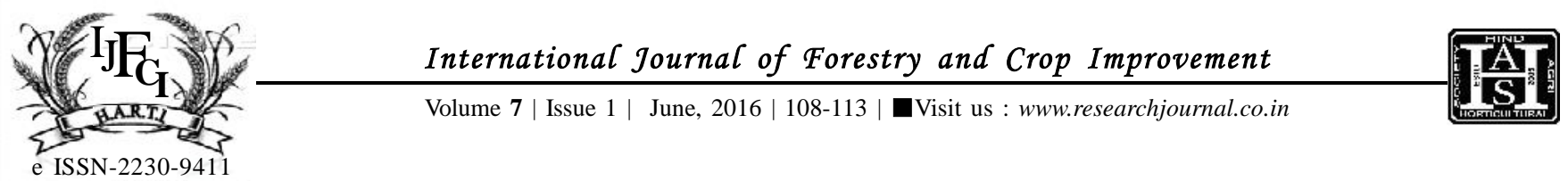

\title{
Knowledge of integrated weed management practices by the farmers in Marathwada region
}

\author{
P.B. GARDI AND R.P. KADAM
}

\begin{abstract}
The present study was conducted in Marathwada region of Maharashtra state. Present study was carried out in randomly selected Parbhani district. Four talukas was selected purposely from Parbhani district by considering highest area and production of the soybean crop namely viz., Purana, Palam, Parbhani and Gangakhed. Three villages from each taluka were selected randomly, thus, the make12 villages were selected for study. Ten respondents were selected from each village with the help of those who have cultivating soybean crop on his farm was selected randomly. Thus, the total 120 respondents were selected for the study. The major soybean crops selected for study because soybean crop is infested by number of weeds like Shippi (Echinochloa crus-galli ), Kena (Commelina benghalensis), Dudhi (Euhorbia spp.), Hazardani (phyllanthus niruri), Nagarmotha (Cyperus rotundus), Hariyali (Cynodon dactylon) etc. which causes loss of farmer upto 40 to 60 per cent in yield, weeds in soybean can be effectively controlled by using integrated weed management practices. Thus, the study was conducted for considering the problem of weed control in soybean crop. Ex-post facto research design was used for present study. The data were collected with the help of personal interview method with the help of interview schedule. It is revealed Table 1 that 69.17 per cent of the respondents were from medium farming experience, 45 per cent respondent were educated upto secondary (middle) school level, 35.83 per cent had small size land holding (upto $2 \mathrm{ha}$ ), 89.17 per cent of the respondents engaged in only agriculture, 78.34 per cent of the respondents were from medium income i.e. (Rs. 77103 to 409000 ) group, 50.84 per cent of the respondents had medium social participation, 62.50 per cent of the respondents used medium sources of information, 59.17 per cent of the respondents had medium extension contact, 59.17 per cent of the respondents had medium level of market orientation, 61.67 per cent, of the respondents had medium level of risk orientation and 62.50 per cent of the respondents had medium level of knowledge.Education, land holding, occupation, annual income, sources of information, extension contact and market orientation and risk orientation had significant relationship with adoption of integrated weed management practices.
\end{abstract}

KEY WORDS : Knowledge, Integrated weed management

HOW TO CITE THIS ARTICLE : Gardi, R.B. and Kadam, R.P. (2016). Knowledge of integrated weed management practices by the farmers in Marathwada region. Internat. J. Forestry \& Crop Improv., 7 (1) : 108-113, DOI: 10.15740/HAS/IJFCI/7.1/108-113.

Article Chronical : Received : 22.03.2016; Revised : 25.04.2016; Accepted : 26.05.2016

\section{MEMBERS OF RESEARCH FORUM}

Address of the Correspondence : R.P. KADAM, Department of Extension Education,

Vasantrao Naik Marathwada Krishi Vidyapeeth, PARBHANI (M.S.) INDIA

Email: rpk.mkv@gmail.com

Address of the Coopted Authors : P.B. GARDI, Department of Extension Education, Vasantrao Naik Marathwada Krishi Vidyapeeth, PARBHANI (M.S.) INDIA 